University of Michigan Law School

University of Michigan Law School Scholarship Repository

\title{
A Vision for Scaling Microfinance: More Than Dollars and Smarts
}

Deborah Burand

Unviersity of Michigan Law School, dburand@umich.edu

Available at: https://repository.law.umich.edu/book_chapters/253

Follow this and additional works at: https://repository.law.umich.edu/book_chapters

Part of the Banking and Finance Law Commons

\section{Publication Information \& Recommended Citation}

Burand, Deborah. "A Vision for Scaling Microfinance: More Than Dollars and Smarts." In Financial Inclusion, Innovation, and Investments: Biotechnology and Capital Markets Working for the Poor, edited by R. D. Christy and V. L. Bogan, 57-72. Singapore: World Scientific, 2011.

This Book Chapter is brought to you for free and open access by the Faculty Scholarship at University of Michigan Law School Scholarship Repository. It has been accepted for inclusion in Book Chapters by an authorized administrator of University of Michigan Law School Scholarship Repository. For more information, please contact mlaw.repository@umich.edu. 
Chapter Four

\title{
$\mathscr{A}$ vision for Scaling Microfinance: More than Dollars and Smarts
}

\author{
Deborah Burand, Esq.*
}

\subsection{Introduction}

When Warren Buffet announced the largest charitable gift in history, namely the contribution of 5/6th of his shareholdings in Berkshire Hathaway to the Bill \& Melinda Gates Foundation, he explained his decision in a pithy soundbite. According to Buffet, "philanthropy is a tougher game" than business: "In philanthropy, the most important problems are those which have already resisted both intellect and money."

When it comes to scaling microfinance, Buffet has it exactly right. Dollars and smarts are not enough to solve the problem of helping microfinance to reach scale. Not even mega-philanthropists like Bill Gates, who

\footnotetext{
*Ms. Burand wrote this paper in 2007 while serving as the Executive Vice President, Strategic Services, Grameen Foundation. She now is the Vice President and General Counsel of the Overseas Private Investment Corporation. This paper borrows heavily from the work of others, like Lee C. Buchheit, Esq., whose eloquent writings on the design of a new international financial architecture inspired this paper. While acknowledging these grand thinkers, all opinions in this article are her personal views and should not be attributed to current or past employers, or, for that matter, to anyone else.

Deborah Burand, Overseas Private Investment Corporation, 1100 New York Avenue, NW, 12th Floor, Washington, DC 20527.
} 
has recently determined to invest, through the Bill \& Melinda Gates Foundation, $\$ 750$ million over the next several years to deepen and expand the reach of financial services to the world's poor, can provide sufficient capital to ensure that microfinance reaches its promise, unless this new breed of philanthropists also invests in building a new international financial architecture that values financial access as highly as financial stability. Simply put, to scale microfinance requires dollars, smarts, and, importantly, a vision for a new financial order, an order that aims at tapping the power of commercial sources of capital to finance the growing funding needs of microfinance providers. ${ }^{1}$

Over a decade ago, on the heels of yet another round of financial crises in the world, starting with the Mexico peso crisis in December 1994, and then followed by crises in Thailand, Indonesia, South Korea, Russia, Brazil and Argentina, policymakers worldwide attempted to build a new "international financial architecture" that could not only prevent future financial crises, but also ease the destructive power of those crises that inevitably occur. The goal of this new international financial architecture was simple: make international capital flows to emerging markets more efficient, stable and transparent. Actually building such a new international financial architecture, however, was anything but simple.

As described by Lee C. Buchheit, Esq. in his 1999 article, "A Lawyer's Perspective on the New International Financial Architecture," this architecture stood on four legs. It aimed to:

(1) Moderate private sector financial flows to emerging markets to avoid a boom/bust pattern of lending;

(2) Ensure that investors in emerging markets had the information and economic incentives to make prudent investment decisions;

(3) Reinforce the ability of debtor countries to endure temporary economic or financial shocks or disruptions; and

\footnotetext{
${ }^{1}$ Some have estimated that today's microfinance providers are in need of $\$ 10-\$ 20$ billion in capital over the next five years.
} 
(4) Facilitate prompt, orderly, non-contagious workouts of debtor countries when crises do occur, with attendant losses falling on those who made the investment decision.

So what does this discussion that so dominated G-7 and G-8 discussions in the 1990s have to do with microfinance reaching scale today? The short answer is - a lot. The longer answer is that many of the tools that were developed in the late 1990s to address macroeconomic challenges in lending to emerging markets are readily transferable to the challenge of bringing microfinance to scale through access to appropriate and sustainable commercial sources of finance. In short, to scale microfinance, we also need to foster capital flows into this sector that are efficient, stable and transparent.

Here is a similarly simple to articulate, but hard to build, vision for scaling microfinance. Take the four legs of the international financial architecture described above, and substitute the words "microfinance providers" for "emerging markets" and "debtor countries," and you have got a concrete vision for scaling microfinance that sounds like this:

"A new international financial architecture is needed to make capital flows to microfinance providers more efficient, stable, and transparent. To this end, a new international financial architecture is needed that will:

(1) Moderate private sector financial flows to microfinance providers to avoid a boom/bust pattern of lending;

(2) Ensure that investors in microfinance providers have the information and economic incentives to make prudent investment decisions;

(3) Reinforce the ability of microfinance providers to endure temporary economic or financial disruptions; and

(4) Facilitate prompt, orderly, non-contagious workouts of microfinance providers when crises do occur, with attendant losses falling on those who made the investment decision."

Visions are as important for articulating not only what one hopes to achieve in the world, but, by inference, also highlighting what one wants to avoid. The above vision statement does both. Moreover, like the four pillars of the international financial architecture described by Buchheit, the above microfinance-oriented pillars are equally split between prevention and 
cure — the first two principles aim at preventing crises, and the second two principles aim at responding to (and possibly curing) crises if and when they arise.

The following is a stock-taking of some of the key initiatives that have taken place to date in the world of microfinance at building an international financial architecture that attracts and retains flows of commercial capital to microfinance. It also is a call to those of us in the microfinance world to do much, much more.

\subsection{Building an International Financial Architecture}

\subsubsection{Moderate Private Sector Financial Flows to Microfinance Providers to Avoid a Boom/Bust Pattern of Lending}

In a series of scenario-building exercises, CGAP (the Consultative Group to Assist the Poor) recently gathered microfinance professionals together to ponder where microfinance may find itself in 2015 and to identify the key drivers of that crystal ball gazing. ${ }^{2}$ One driving factor identified by those of us at the table was the growing enthusiasm by investors for investing in microfinance, an enthusiasm that also has been noted in a recent study undertaken by MicroRate of the mushrooming number of specialized microfinance investment vehicles (called by MicroRate, "MIVs"). According to some estimates, there are now over $80 \mathrm{MIVs}$ in the world, and that number continues to grow. CGAP research suggests that the amount invested in MIVs doubled in the last year, from $\$ 987$ in 2005 to $\$ 2$ billion in 2006. Much of the MIV investment in microfinance providers to date has been in the form of debt (as opposed to equity); and of that debt, most has been denominated in hard currency. ${ }^{3}$ Yet most microfinance

\footnotetext{
2 See CGAP Focus Note No. 39, "Financial Inclusion 2015: Four Scenarios for the Future of Microfinance" (October 2006).

${ }^{3}$ A CGAP-MicroRate survey from 2005 finds that 74\% of MIV investment has been provided in the form of debt; and of that debt, $70 \%$ has been denominated in hard currency.
} 
institutions (MFIs) are still underleveraged relative to commercial banks. ${ }^{4}$

This growing interest in investing in microfinance is a blessing for the industry; but, like all blessings when taken in too strong a dose, it may also be a curse. While neither CGAP nor MicroRate have described these new sources of funding as a lending "boom" or "bubble," the risk is there as most serious observers of microfinance will admit, albeit quietly.

Several observers have suggested that some of the recent investments in microfinance may have been attracted more by the underlying subsidies supporting those transactions (such as credit enhancements provided in the form of a donor-funded or otherwise highly subsidized guarantee) than by the actual cash flow of the underlying microfinance business activity being financed. Put differently, does it matter to an investor in search of investment grade paper if the business she is financing is microfinance, or is she solely in search of investments that enjoy highly rated, credit support? Whether this is an accurate perception of investors' motivations, the risk is that today's chatter about the glories of investing in microfinance may eventually wane, as financial enthusiasm often does, and then investors' enthusiasm will swing to the next new thing.

In the meantime, however, some MFIs are enjoying their moment in the sun. ${ }^{5}$ With no spoilsport like former Federal Reserve Board Chairman Alan Greenspan in sight who threatens to take away this punch bowl of bubbling capital, some MFIs are borrowing at record levels often with little understanding of the true costs and structural or documentation risks of their borrowings (as evidenced by a growing number of covenant defaults quietly taking place among microfinance borrowers). ${ }^{6}$ They are borrowing in dollars and euros to fund assets denominated in local

\footnotetext{
4 The median MFI debt:equity ratio of MFIs reporting to the MIX (Microfinance Information eXchange) is around 2:1, compared to commercial banks that are leveraged at a rate that is closer to $9-12: 1$.

5 The above referenced CGAP survey from 2005 finds that ten microfinance institutions attracted $26 \%$ of the aggregate amount of MIV investment.

${ }^{6}$ CGAP and Grameen Foundation recently surveyed the management teams of 16 MFIs in 14 countries around the world, half of which mobilize and intermediate deposits. A key finding of that survey is that many of the surveyed MFIs are underestimating the true costs and risks of their funding sources - debt and equity.
} 
currencies, with little to no hedges or other risk mitigation strategies to guard against foreign exchange risks. ${ }^{7}$ They are borrowing in short-term or demand funds to finance medium-term assets. They are borrowing at floating interest rates to finance assets earning fixed returns. They are signing loan documentation without understanding (or, as at least one MFI has confessed, even reading) the terms. They are "pledging" microcredit portfolios to secure borrowings in countries where such pledges of intangible assets are legally unenforceable, and some are even "over-pledging" by giving multiple lenders claims on the same asset. All of which suggests that moderating financial flows while stepping up investment readiness training for MFIs might be an increasingly desirable goal.

When the international financial architects of the 1990s attempted to come up with measures that would moderate financial flows to emerging markets, they looked to tools and practices that would discourage excessive borrowing as well as flows of "hot money" (meaning short-term, hard currency-denominated, financing). This caution is something that could and should take hold in the microfinance world too.

While some investors in microfinance have complained recently that there is more funding than suitable microfinance investments, one needs to ask whether the funding being pushed at microfinance providers is itself "suitable." What kind of commercial sources of funding do we want to see invested in microfinance? Can a sustainable microfinance industry be built on the back of short-term loans, denominated in hard currency? Would it be a good thing for the overall health of the microfinance industry if it were to come to rely on large capital flows from internet-based platforms that intermediate the extension of six-month, dollar-denominated loans from, say, college students in Ithaca, New York to poor basketmakers in Benin City, Nigeria - even if such loans are made at zero percent interest rates? Do we think it is appropriate for MFIs to execute complex loan agreements containing covenants that they have not read, do not understand, or, if having read and understood, have little likelihood of meeting? If the answer to any of these questions is no, then

\footnotetext{
7 See CGAP Focus Note No. 31, "Foreign Exchange Rate Risk in Microfinance: What is it and how can it be managed?" (January 2005).
} 
much work needs to be done on both the demand and supply side of the equation - work that would encourage responsible borrowing by microfinance providers and discourage irresponsible lending to microfinance providers by investors.

Developing standard forms of loan documentation for the microfinance industry that fairly represents the interests of both the borrower and lender is one important step that could be taken in this direction. Not only could this standardization offer valuable time savings to both lenders and MFIs as it would cut substantially time spent in negotiations, but standardized loan documentation could lead to a more liquid market in the trading of microfinance loans (or even securitization of such loans), which in turn should lower MFIs' cost of funds so that they can serve their poor clients more efficiently and cheaply.

Training microfinance providers to learn how to negotiate and understand better those contractual obligations that they are assuming when tapping commercial sources of financing is another important step. MFIs also need more tools to help them evaluate the costs and risks of varying commercial funding sources. Happily, donors like Rockdale Foundation and other industry stakeholders, like CGAP, are now investing in the creation of a growing array of technical guides and tools to help MFIs better understand the structure and documentation of various forms of financings. ${ }^{8}$ Additionally, regional and global microfinance networks increasingly are running investment-readiness trainings for MFIs and some, like Grameen Foundation's Capital Management and Advisory Center (CMAC), now offer advisory services directly to individual MFIs to support the evaluation, negotiation and structuring of their commercial financings.

Building tools to help microfinance institutions better hedge against currency and interest rate risks is yet another step. Given the recent

\footnotetext{
${ }^{8}$ See, for example, "Commercial Loan Agreements: A Technical Guide for Microfinance Institutions" (prepared for CGAP by Cleary, Gottlieb, Steen \& Hamilton (2006)), and "Foreign Exchange Risk Mitigation Techniques: Structure and Documentation, A Technical Guide for Microfinance Institutions" (also prepared for CGAP by Cleary, Gottlieb, Steen \& Hamilton (2006)). Both of these technical guides have been translated into several languages and are downloadable from the CGAP website (www.cgap.org).
} 
increase in international lenders' interest in microfinance, the need for instruments to mitigate cross-border lending risks, including foreign exchange and interest rate risks, has grown. Because of the relatively small size of MFI borrowings, perceived counterparty risk of MFIs, and often exotic currencies used in MFIs' operations, standard hedging tools, like foreign exchange forwards, futures, swaps or options, often are not available or are too expensive for microfinance providers to access. One breakthrough under discussion is the possible launch of a foreign exchange hedging fund, supported in part by the Dutch, and aimed at small and medium enterprises, including microfinance providers.

Finally, other stakeholders — ranging from bank regulators to rating agencies to existing investors in microfinance — should voice dismay when they observe excessive or inappropriately structured borrowings by MFIs or flows of "hot money" coming into the microfinance industry. In this regard, welcome steps are being taken by some of the specialized microfinance rating agencies to draw attention to the amount of MFIs' unhedged foreign currency exposure.

\subsubsection{Ensure that Investors in Microfinance Providers Have the Information and Economic Incentives to Make Prudent Investment Decisions}

Transparency is a watchword in the microfinance industry, just as it was in the 1990s for would-be international financial architects. According to a common dictionary definition found in Merriam Webster's Collegiate Dictionary, "transparency" means to be free from pretense or deceit, to be easily detected or seen through, and, finally, to be readily understood.

There is now near universal recognition that transparency in the marketplace is a good thing. The more transparency, the better. Even microfinance has become enamored with transparency, as evidenced by CGAP's award each year to the world's most transparent microfinance provider. But transparency for transparency's sake somehow misses the point. The world of microfinance, just as the world of international capital markets, needs transparency in order "to be readily understood." And that 
is a challenge for microfinance, particularly with the growing number of investors who are intent on making cross-border investments into microfinance.

In October of 1933, John Foster Dulles, writing in Foreign Affairs, concluded his article on "The Securities Act and Foreign Lending" with the following admonition about the need for understanding risk when investing across borders:

The remedy... is not to be found in legislative restraints .... Rather it calls for our education in financial matters, to the end that foreign risks will be recognized and appraised and assumed deliberately only by those who can afford them.

That advice rings true today. The risks of spikes in repayment defaults by borrowing microfinance providers, or of the proliferation of loan agreements being signed by MFIs that contain overly broad cross-default clauses that are certain to tumble one distressed loan after another in a domino-effect, can be addressed only if the microfinance industry takes it upon itself to understand better the fruits of our transparency campaign.

An analogy can be made to the shaky start of eco-tourism in Latin America in the mid-to-late 1980s. Adventuresome tourists, fresh from camera-popping safaris across African savannahs, came to the rainforests of Bolivia and Brazil in search of equally riveting photo-opportunities and communes with nature. At first they often were disappointed. For those of us working on international environment issues and who hoped to captivate this new breed of eco-tourists (and their wallets), we soon learned that it was not enough to bring them to one of the most diverse ecosystems on earth, we also needed to help our fellow wanderers understand the beauty and complexity of what they were seeing. That is, we needed to make the wonders of the rainforest more "transparent."

Some may argue that the goal of building an "international financial architecture" is too rigid and static to encompass the fluidity of the fastchanging world of microfinance. And they may be right. Perhaps, again borrowing from the world of eco-tourism, the better analogy is to build a transparent "ecosystem" for investors in microfinance. But for the ecosystem of microfinance to be truly transparent engenders a responsibility on all 
of us in the microfinance world not simply to push for a dump of economic, financial, and social performance data on current and would-be investors in microfinance. Rather, we have a responsibility to develop and refine microfinance institutions' capacity to present those numbers and statistics in ways that lead investors from seeing to understanding.

An important step being taken in this direction is the development of microfinance benchmarks, which allow the financial and operational performance of microfinance providers to be compared against each other. Just a decade ago, data about microfinance performance was largely anecdotal, and, where there was quantitative data, it was focused largely on the performance of MFIs working in Latin America. Today, by contrast, there is standardized quantitative financial and operational data available to the public for nearly 1,000 microfinance providers located in all regions of the world, of different legal forms (ranging from regulated banks to unregulated non-profits), and at different stages of institutional development (commercializing, transforming, deposit-taking, etc.). ${ }^{9}$ This has allowed benchmarking by geographic region, by legal form, and by stage of institutional development that can be used by investors, policymakers and MFI management to inform decisionmaking.

Steps to supplement these financial and operational benchmarks with social performance benchmarks, such as the growing adoption by povertyfocused MFIs of the Grameen Foundation's Progress out of Poverty Index (also called PPI) that provides statistically robust data on the likely poverty levels of MFI clients, will be an important leap forward to educate sociallyminded investors as they seek to invest in double bottomline providers of microfinance.

Similarly, the expected launch of an association for retail microfinance investors is a needed addition to the evolving microfinance "ecosystem." Such an association should take a leadership role in conducting meaningful research about the risks and rewards of investing in microfinance, and in disseminating that research to a broad commercial, retail investor base.

\footnotetext{
9 This information can be accessed through the Microfinance Information eXchange (MIX) at www.themix.org.
} 


\subsubsection{Reinforce the Ability of Microfinance Providers to Endure Temporary Economic or Financial Disruptions}

As net private capital flows to emerging markets now run at an annual rate of $\$ 500$ billion (a more than fourfold increase from 2002), the microfinance industry has also enjoyed a wave of new investors and access to new (at least to microfinance) financial products, such as CLOs (collateralized loan obligations), syndicated loans, securitization of microcredit portfolios, IPOs, private placements, and bond offerings, to name a few. If, or as some suggest when, the tide turns, and the recent years' rush of capital into emerging markets starts to rush back out again, the funding of microfinance may also take a downward turn.

In the past, there was evidence that microfinance providers (and their clients) were not particularly affected by financial shocks to the formal economies where they operated. Whether the commercialization and integration of microfinance providers into the more formal economies where they work changes this risk calculation is deserving of more research. ${ }^{10}$ As microfinance becomes increasingly integrated into financial markets and the formal sector, one can no longer assume that microfinance providers will continue to enjoy a counter-cyclical position within their respective financial sectors. Rather, we may find that the risks of investing in microfinance are more correlated to broader macroeconomic indicators than in the past. If this is the case, then the fates of commercially-funded microfinance providers will likely rise or fall in step with the financial fortunes of both the countries where they work and the countries where their investors raise capital.

\footnotetext{
10 Some are starting to attempt this research although the data samples often are small and findings are untested given the dearth of recent financial or economic crises in the developing world. See, for example, a recent working paper from the Stern School of Business of New York University, which suggests that the performance of microfinance providers is less correlated to domestic macroeconomic conditions than is the performance of comparable commercial banks. See Financial Times, "Microfinance: Not as risky as you think," by Kathryn Tully (May 25, 2007).
} 
Protecting microfinance providers, and, equally important, their clients — the microentrepreneurs - from unexpected, temporary economic or financial disruptions is an area of growing concern among microfinance stakeholders. Moreover, since MFIs often work in disaster-prone or conflict-ridden areas, these economic or financial disruptions may be based on a natural disaster such as a flood or earthquake, or a manmade disaster such as war or civil strife. The challenges facing microfinance providers that choose to serve poor clients living in "risky areas" may have everything to do with where microfinance providers work and very little to do with how well they work. Not surprisingly, many microfinance providers share in common with their target clientele, the poor of the world, a high degree of vulnerability to risks outside of their control. Yet microfinance providers have more resources at their disposal than do their poor clients to manage these risks. Unfortunately, not enough microfinance managers are acting proactively to mitigate or spread these risks to those in the financial world that are better equipped to handle such disruptions.

One step that some have taken is to set up contingent credit lines or emergency liquidity funds that are aimed at giving microfinance providers breathing room should traditional sources of funding suddenly dry up or disasters strike causing their clients to default on loan repayments. Another step that is being explored is the development of insurance products aimed at mitigating or insuring against catastrophic risks. Weather-indexed insurance, credit insurance, and catastrophic loss of business insurance are just a few of the products now being designed specifically with the needs of MFIs and their clients in mind. Over time, one can imagine even the re-engineering of catastrophic bonds (so-called "CAT" bonds) to meet the needs and particularized risks of the microfinance market, perhaps to be called micro-CATs.

Laudable as these risk-sharing financial instruments may be in helping MFIs manage risk without overly limiting their outreach to the poor, this is an area that is still new to much of the microfinance industry and where much more attention is needed. Insurance and re-insurance companies have much to contribute to this area. Similarly, just as investment readiness training is an important pre-condition to attracting sustainable flows of commercial capital to microfinance, so too is risk-mitigation training a pre-condition to helping MFI managers anticipate and plan for temporary 
economic or financial disruptions when those capital flows are interrupted by events outside of their control.

Enhancing the risk management capacity of MFI managers and spreading of catastrophic risks to other financial actors that are better equipped to manage those risks should be welcome by local regulators as well as investors. In the absence of these risk-sharing or off-loading arrangements, some bank regulators are pondering the introduction of front-loaded, preventive measures into their specialized microfinance laws and regulations so as to limit the chance of seeing deposit-taking MFIs encounter a liquidity crisis or insolvency. These regulators are beefing up their specialized microfinance laws and regulations aimed at loan concentration limitations, capital adequacy ratios, asset classification, provisioning, liquidity reserve requirements, management information systems, and governance. It is not unusual, for example, for regulators to subject deposit-taking MFIs to capital adequacy ratios that are more onerous than those applied to local commercial banks. Instead of the more typical $8 \%$ capital requirements imposed under Basel I to assets that are risk-weighted at 100\%, some regulated microfinance institutions are being required to hold capital in amounts of $15 \%$ or more against $100 \%$ of their outstanding microcredits. In essence, to address regulators' concerns about the ability of deposittaking MFIs to find adequate sources of capital in the face of a weakening loan portfolio, they are requiring these MFIs to build relatively larger equity cushions than that required of commercial banks. Finding alternative ways to manage this risk should lower regulatory-imposed transaction costs to the benefit of both MFIs and the clients of MFIs.

\subsubsection{Facilitate Prompt, Orderly, Non-Contagious Workouts of Microfinance Providers When Crises Do Occur, with Attendant Losses Falling on Those Who Made the Investment Decision}

This is the area where the least work has been done in the microfinance sector, perhaps understandably so as there are few examples to date of repayment defaults by microfinance providers. Yet lack of workout experience 
in the microfinance sector should not excuse a lack of planning for this eventuality. The time is now, before a crisis occurs, to train microfinance providers in sound debt management policies, to help them understand the role that 3rd party credit enhancements can (and cannot) play when crises occur, to ensure that only meaningful pledges of assets are offered by MFIs to lenders, and to instill a healthy respect in borrowing MFIs for the complications of managing loan obligations that enjoy sweeping cross-default clauses, to name a few.

Finally, there is a regulatory and legal enabling role to be played here too. Investors need to understand better where they stand vis-à-vis other claimants with respect to MFIs' assets should a workout become necessary. For example, does an unsecured lender to a deposit-taking MFI stand in front of or behind depositors when it comes to claiming the MFI's assets in the case of a bankruptcy? Ask one of today's lenders to a regulated microfinance provider and see if he or she knows the answer to this question. Still more troubling, ask a local bank regulator and see if he or she knows.

Moreover, in countries where the application of bankruptcy laws to MFIs is uncertain, policymakers have an opportunity to clarify, before the fact, the various priority positions of various classes of investors in MFIs so that these investors understand their legal rights and the priority of claims. This also avoids the making of politicized decisions about claimants' rights in the heat of a workout. As a general rule, all MFIs, even non-profit MFIs that are organized under charitable institution laws rather than corporate laws, should enjoy bankruptcy protections that customarily are made available to corporate borrowers, such as the protection against set-off.

Similarly, the applicability and appropriateness of the corrective action tools available to bank regulators need to be reassessed before such tools are applied to regulated MFIs. For example, a "stop lending" order imposed by a bank regulator on a weakening MFI is likely to push that MFI to quickly fail given the often vital importance of ongoing lending operations to the health of its existing microcredit portfolio. Additionally, while the world has seen "borrower runs" on MFIs, there is still much to be learned about how to manage "depositor runs" on regulated MFIs. This can be complicated by the unique nature of those depositors - a possibly physically remote, widely spread, illiterate group of poor individuals who likely will be unimpressed by the publication of financial statements in newspapers 
or financial ratings posted in MFI offices. All of which points to the need for more work to be done in the area of building deposit insurance schemes and other measures that are aimed at protecting this unusual group of depositors and assuaging their fears before a crisis occurs or before the failure of one deposit-taking MFI sparks a contagious depositor run on other microfinance providers.

In conclusion, the day that Warren Buffet made the decision to contribute the lion's share of his wealth to the Bill \& Melinda Gates Foundation was a good day for all of us who champion the cause of poverty alleviation and increased financial access in the world. Yet microfinance holds a promise that does not wholly depend on future billionaires' generosity. That is because microfinance can reach scale without depending on the largesse of the rich, so long as the microfinance sector can tap the power of commercial sources of capital for the sector's needs. But such capital flows to microfinance need to be efficient, stable, and transparent, otherwise the gains in scale achieved by tapping the power of commercial capital will be unsustainable, and much needless damage will occur when money rushes out of the microfinance sector just as quickly as it is now rushing in.

Here is one important way to spend at least a small portion of Warren Buffet's bequest to the Bill \& Melinda Gates Foundation - namely, to invest in the building of an international financial architecture for the microfinance sector. But as Mr. Buffet also has acknowledged, it takes more than dollars and smarts to tackle the world's most important problems. As argued in this paper, it also takes vision. It is time for a vision of a new financial order to take root in the world, a vision that is intent on scaling microfinance by tapping the power of the capital markets and that prizes financial access as well as stability. 
This page intentionally left blank 